\title{
A heat energy recovery system from tunnel waste water
}

1 Nicholas Hytiris BSc, MSc, PhD

Senior Lecturer, School of Engineering and Built Environment, Glasgow Caledonian University, Glasgow, UK

2 Konstantinos Ninikas BSC

Associate Researcher, School of Engineering and Built Environment, Glasgow Caledonian University, Glasgow, UK (corresponding author: kninikas@yahoo.gr)
3 Rohinton Emmanuel BSC, MSc, PhD

Professor, School of Engineering and Built Environment, Glasgow Caledonian University, Glasgow, UK

4 Bjorn Aaen BSc, MEng Visiting Lecturer, School of Engineering and Built Environment, Glasgow Caledonian University, Glasgow, UK

5 Paul L. Younger BSC, MSc, PhD, FREng Professor, School of Engineering, University of Glasgow, Glasgow, UK
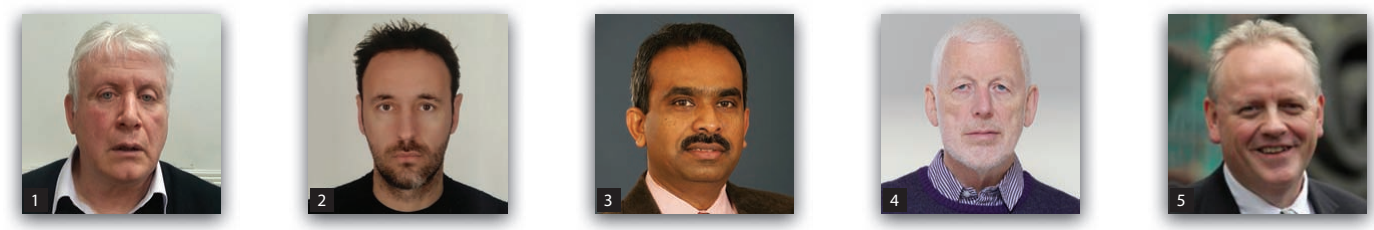

Minimising the maintenance costs of water ingress in transportation tunnels is a significant challenge. Decreasing the overall cost of a ground source heat pump system is equally challenging. An effort to address both issues at once has been made in relation to groundwater ingress in the Glasgow Subway system. Inflowing water is a valuable resource which could be channelled through a water source heat pump (WSHP) to produce heat energy for domestic or public use (heating and domestic hot water). Water flow and water temperature have been recorded for a year at 21 different points within the network of the underground tunnels and platforms. The points of highest water influx were identified, and the heat energy content of each has been calculated. Working from these data, several options were identified for capturing the water and diverting it to a WSHP to recover heat. A final design for a pilot system within the tunnels was developed. The findings of this study are expected to contribute a renewable heat solution through a cost-effective heat pump system design.

\section{Notation}

$\mathrm{COP}_{\mathrm{H}}$ coefficient of performance

$E \quad$ required energy: $\mathrm{kW}$

$G \quad$ heat energy flux: $\mathrm{kW}$

$H \quad$ total heating effect

$S_{\mathrm{VC}} \quad$ specific heat capacity of water: $\mathrm{J} /(\mathrm{l} \mathrm{K})$

$Z \quad$ flow rate: $1 / \mathrm{s}$

$\Delta \theta \quad$ temperature drop: ${ }^{\circ} \mathrm{C}$

$\rho \quad$ density of water: $\mathrm{kg} / \mathrm{m}^{3}$

\section{Introduction}

The need for finding alternative sources to replace conventional fuel is becoming more and more urgent. The basic factors that have led the UK government to favour more environment-friendly methods of heating are the obligation of reducing the carbon dioxide $\left(\mathrm{CO}_{2}\right)$ emissions to the 1990s' levels by 2020 (Scottish Government, 2012) and to reduce fully the carbon dioxide emissions of heating by 2050 (Climate Change Act 2008, 2008). Ground source heat pump (GSHP) systems have shown the potential to reduce energy consumption, and as a result, a carbon dioxide reduction (Ground Source Heat Pump Association, 2015) compared with conventional heating systems (electricity, oil, gas).
Heat pumps have long been a key technology for exploiting lowgrade heat. They use compression (the same principle as a refrigerator) to extract tepid low-grade heat to produce heat for space and/or water heating in general (NRC, 2015). They can also be reversed to produce cooling. Heat pumps are designed to move thermal energy opposite to the direction of spontaneous heat flow by absorbing heat from a cold space and releasing it to a warmer one. A typical heat pump uses less energy input (compared to all other conventional heating means, e.g. gas and petrol) to accomplish the work of transferring energy from the heat source (aquifer) to the destination for space heating/hot water (Branz, 2015).

This study has investigated the possibility of harvesting heat from the water ingress inside Glasgow's Subway tunnels by using a heat pump. The Glasgow Subway is a circular underground passenger railway system in the centre and west of the city. It contains twin tunnels, allowing clockwise circulation of trains on the 'outer' circle and anticlockwise on the 'inner' circle. Fifteen stations are distributed along the route length of just over $10 \mathrm{~km}$. The River Clyde dissects the circular route, with eight stations north of the river and seven to the south, as shown in Figure 1. 


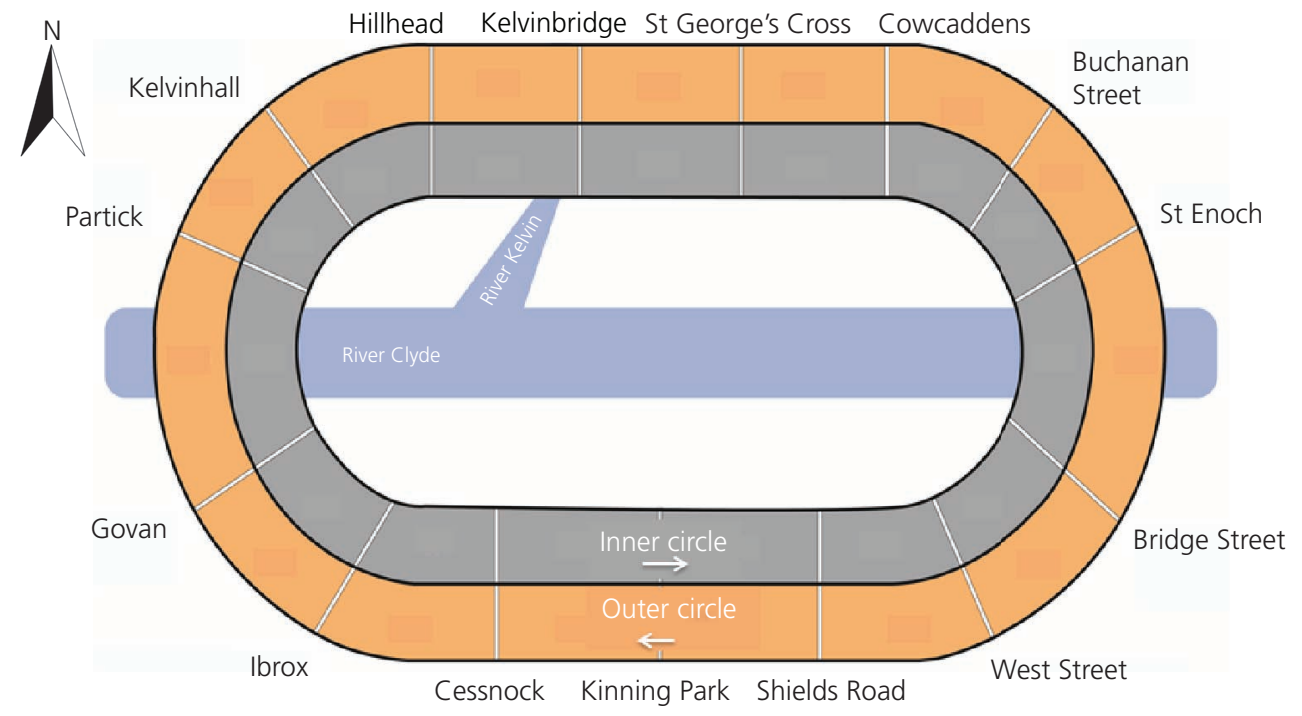

Figure 1. A typical Glasgow Subway map

At present, water ingress into the subway tunnels causes environmental (water pollution), operational (interference with train operations) and aesthetic (unsightly) problems. The authors attempt to explore the possibility of turning this multifaceted problem into an opportunity for space heating and domestic hot water (DHW) through a WSPH, which is a type of geothermal heat pump system.

Geothermal heat pumps are of two types: closed-loop systems and open-loop systems (US DOE, 2015). A closed-loop system heat pump - usually called a GSHP - circulates an antifreeze solution through a closed loop that is buried in the ground or submerged in water. A heat exchanger transfers heat between the refrigerant in the heat pump and the antifreeze solution in the closed loop. The loop can be in the following configurations: horizontal, vertical or pond/lake. Such a closed-loop system has been implemented at the Budapest Metro (BKV Zrt, 2011) to provide space heating and hot water for one station. An array of pipes embedded in the platform maintains the water at a stable temperature.

An open-loop system heat pump - usually called a water source heat pump (WSHP) - uses well or surface water as the heat exchange fluid that circulates directly through the system. The water returns into a recharge well or surface discharge afterwards. This is a practical option when there is an adequate supply of water. This is the case in the location of this case study, where a WSHP through an open-loop system is expected to provide heating through the constant water ingress into the subway tunnels.

\section{Methodology}

The problem of water ingress into the subway tunnels requires frequent emptying of water collected in sumps into the city's sewer system. The sumps (Figure 2) are generally flat-bottomed rectangular chambers formed either within the tunnel invert or station platforms and range from 0.50 to $2.50 \mathrm{~m}$ deep from the access level. The pumping stations inside each sump are generally equipped with two submersible pumps. The excess water from the tunnels is pumped out and discharged into the sewerage network adjacent to each station. A total of 21 sumps located inside the tunnel system had been monitored (Figure 3).

A series of measurements were undertaken from May 2014 to April 2015 in all sumps: water flow and water temperature and outdoor weather conditions were simultaneously measured for a year (May 2014 to April 2015). Geological and geotechnical parameters around each station were also studied to identify sites suitable for heat pump locations. Water sampling was carried out at all sumps for the chemical analysis of the water regime.

In addition to the above, outdoor weather data were also compiled simultaneously (temperature, humidity, atmospheric pressure and rainfall), using Glasgow Caledonian University's meteorological station located in the Glasgow city centre in close proximity to the underground tunnel network.

\section{Water flow measurement \\ Drop test}

In each sump, there is a probe that when the water reaches a certain level the pump starts pumping the water out of the sump. This period is called 'active time'. When the pump stops functioning, the water level rises up to a point that the pump will start working again. This period is called 'inactive time', and this is the actual water flow. Given that the dimensions of each sump are known, the water flux is calculated by measuring the difference in water level inside the sump during the inactive time (Figure 4).

This height difference between the active and the inactive time multiplied by the area (surface) of the sump gives the water volume that is being pumped out. Dividing this volume by the time 
Environmental Geotechnics

Volume 5 Issue EG5
A heat energy recovery system from

tunnel waste water

Hytiris, Ninikas, Emmanuel, Aaen and Younger

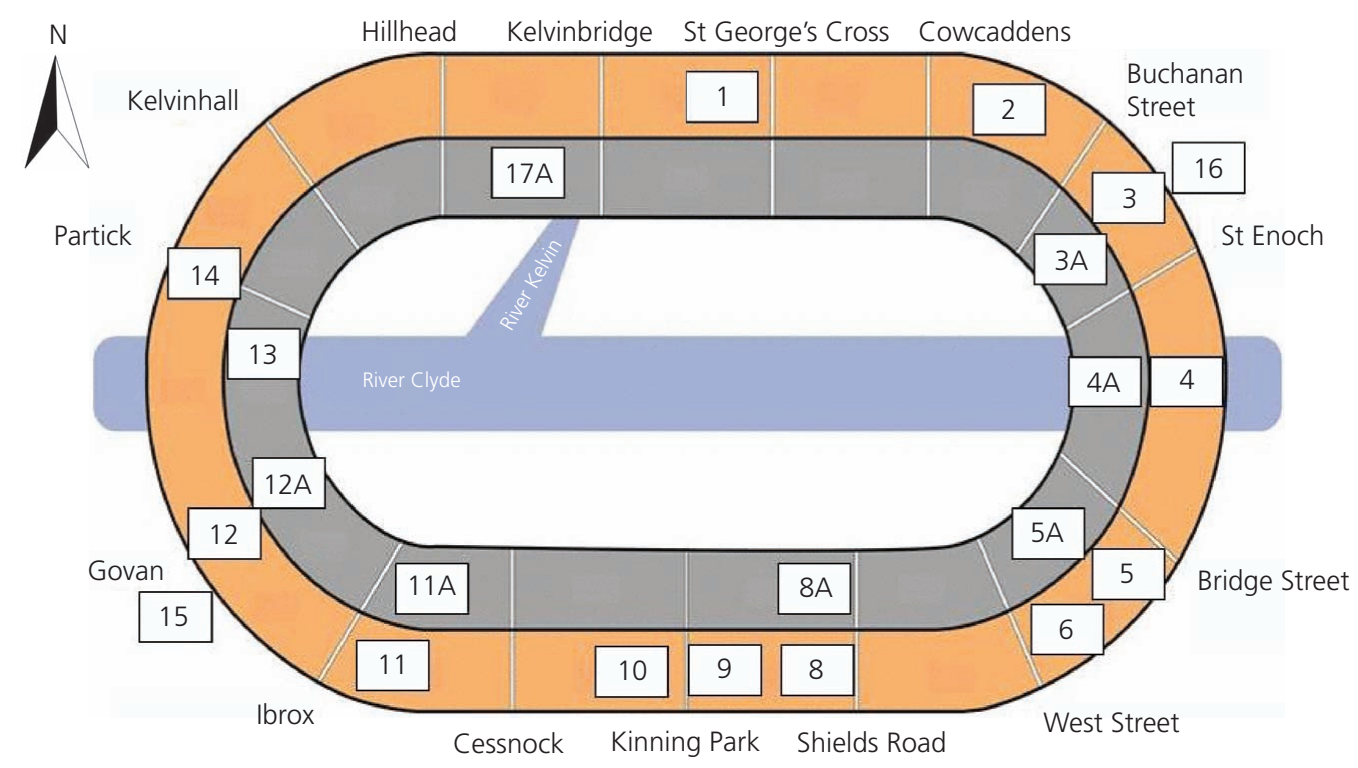

Figure 2. Sump locations in the Glasgow Subway system

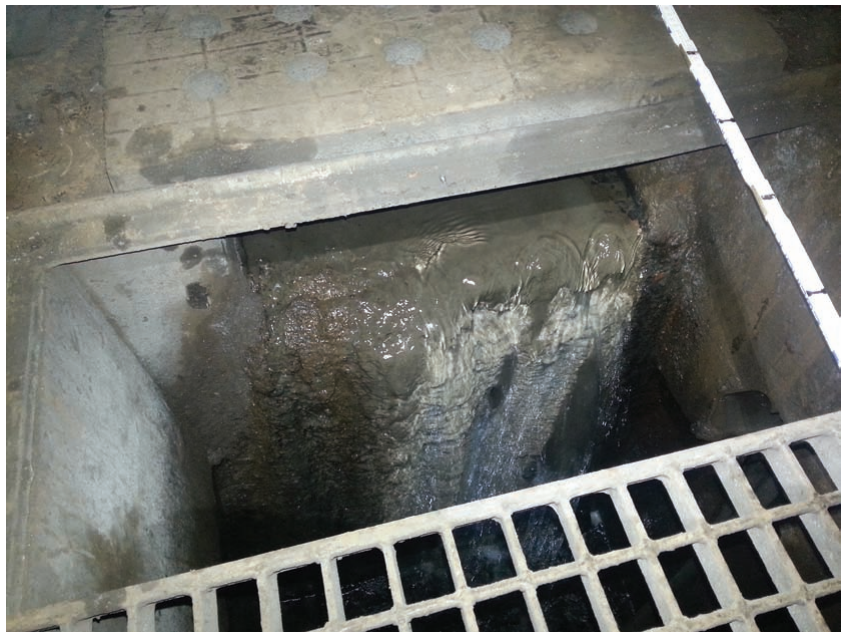

Figure 3. A typical sump located between the rail tracks in the Glasgow Subway system

(seconds) that the pump is active gives the discharged volume during the active time of the pump. The water flow value during the active time (when the water was discharged) was cross-checked with an additional flow measuring method as described in the following.

From the lower point when the pump has stopped to the time that the water takes to reach again the highest point in the sump was also measured (i.e. until the pump starts working again). This depth multiplied by the sump surface gives the water volume that flows into the sump in a specific period of time $(F)$. This is the average water flux in each sump. At least two consecutive measurements were undertaken every month during each site visit in each sump to have more accurate averages of the water flux. If the water flow values during those two measurements had a difference of more than $5 \%$, another two measurements were undertaken. The differences between the two methods were below this limit throughout the monitoring period.

Readings were taken with a rigid measuring stick as well as with an automated depth meter, in which a water-sensitive sensor at the end of the measuring cord completes a circuit when it touches the water level, sounding a buzzer. This calibrated cord indicated the distance from both of the water levels to the surface.

\section{Ultrasonic flow meter}

In order to cross-check the water flux in each sump, a second method was used as well. A digital ultrasonic 'clamp-on' flow meter was used to provide more accurate water flow measurements (Dynasonics TFX/DMS 1002 ultrasonic flow meter with clamp-on pipe transducer). The device was calibrated prior to each measurement by inputting in the software the pipe material (unplasticised polyvinyl chloride or steel), the diameter of the pipe (ø120 or ø160) and the liquid that goes through the pipe, in our case: water.

The portable transducers (Figure 5) were clamped onto the pipe, applying also liquid silicon to the transducers to assist in 'reading' the flux. This enables the flow meter to show the water flux (Figure 6).

\section{Temperature measurements}

Water temperature was measured inside each sump, and the average was calculated. A digital thermometer with an external probe (Tinytag, TGP-4020, range $=-40$ to $+125^{\circ} \mathrm{C}$, accuracy $=$ $\pm 0.35^{\circ} \mathrm{C}$ in the $0-60^{\circ} \mathrm{C}$ range) was used to record the temperature every $10 \mathrm{~s}$. The thermometer was kept in place for 2 min (as a minimum), so a minimum of 12 temperature measurements were received from each measuring point (Figure 7). 
Environmental Geotechnics

Volume 5 Issue EG5
A heat energy recovery system from

tunnel waste water

Hytiris, Ninikas, Emmanuel, Aaen and Younger

Sump 1

Sump's dimensions: $2.00 \times 0.90 \times 2.15$ (overall depth) Area (surface of the sump) A $\quad 1.80 \mathrm{~m}^{2}$

\begin{tabular}{|c|c|c|c|c|}
\hline \multirow[b]{3}{*}{ ta } & Pump started & & & \\
\hline & Start level - (higher point) & B & $1 \cdot 11$ & $\mathrm{~m}$ \\
\hline & Stop level - (lower point) & C & 0.31 & $m$ \\
\hline$\frac{E}{Q}$ & Depth dropped $(B-C)$ & $\mathrm{D}$ & 0.80 & $\mathrm{~m}$ \\
\hline$\stackrel{\oplus}{亏}$ & Volume $(A \times D)$ & E & $1 \cdot 44$ & $m^{3}$ \\
\hline$\stackrel{\widetilde{\pi}}{\stackrel{\mathscr{d}}{\varepsilon}}$ & Time & $\mathrm{F}$ & $\frac{138}{2^{\prime} 18^{\prime \prime}}$ & $\begin{array}{l}\mathrm{s} \\
\min ,\end{array}$ \\
\hline$\star$ & Flow (E/F) & G1 & $\begin{array}{r}0.01043 \\
10.43\end{array}$ & $\begin{array}{l}\mathrm{m}^{3 /} / \mathrm{s} \\
1 / \mathrm{s}\end{array}$ \\
\hline & tal vol. discharged $(\mathrm{G} 1 \times \mathrm{F})$ & G2 & $1440 \cdot 00$ & I \\
\hline
\end{tabular}

\begin{tabular}{|c|c|c|c|}
\hline \multirow{7}{*}{ 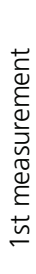 } & Pump stopped & & \\
\hline & Start level - (lower point) & C & $0.31 \mathrm{~m}$ \\
\hline & Stop level - (higher point) & B & $1.13 \mathrm{~m}$ \\
\hline & Depth raised $(B-C)$ & D & $0.82 \mathrm{~m}$ \\
\hline & Volume $(A \times D)$ & $E$ & $1.48 \mathrm{~m}^{3}$ \\
\hline & Time & $F$ & $\frac{790 \mathrm{~s}}{13^{\prime} 10^{\prime \prime}} \mathrm{min}, \mathrm{s}$ \\
\hline & Flow (E/F) & G2 & $\begin{array}{c}0.00187 \mathrm{~m}^{3} / \mathrm{s} \\
1.87 \mathrm{l} / \mathrm{s}\end{array}$ \\
\hline
\end{tabular}

Figure 4. Two consecutive water flow measurements in sump 1

\section{Results}

Perennial water inflow was observed in only three out of a total of 21 sumps: 1, 2 and 17A (Figure 1). Water flow rates and temperature values are shown in Tables 1-3. Outside temperature and relative humidity values are also shown in these tables for reference. The following five stations are the closest to those three sumps with the highest and perennial water flux: Buchanan Street, Cowcaddens, St George's Cross, Kelvinbridge and Hillhead (Figure 1)

To assess where heat output could be delivered and used, a heat load calculation (in kilowatts) in accordance with BS EN 12831:2003 (BSI, 2003) was completed for each of the above five

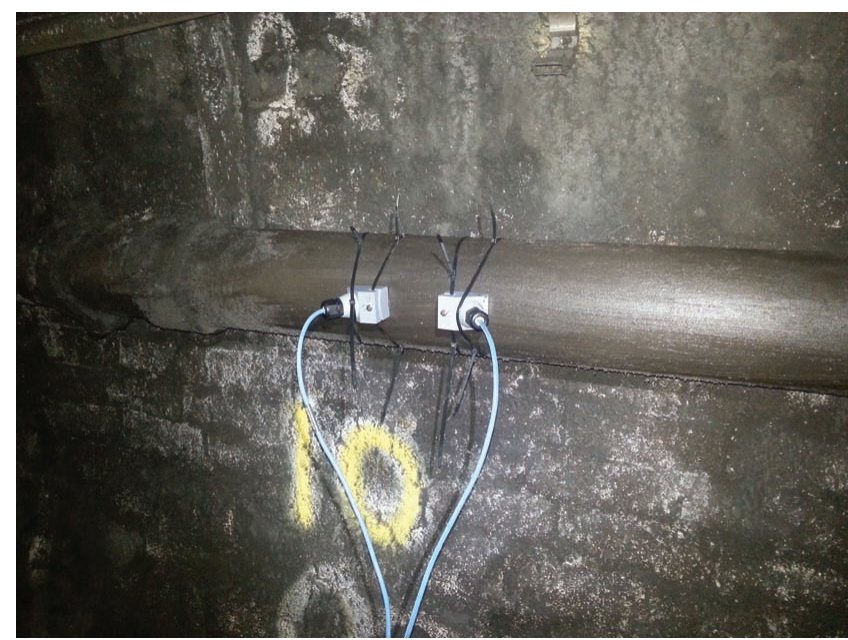

Figure 5. The transducers clamped onto the discharge pipe
Sump's dimensions: $2.00 \times 0.90 \times 2.15$ (overall depth) Area (surface of the sump) A $1.80 \mathrm{~m}^{2}$

\begin{tabular}{|c|c|c|c|c|}
\hline \multirow{8}{*}{ 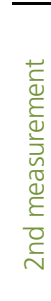 } & \multicolumn{2}{|l|}{ Pump started } & \multirow[b]{2}{*}{$1 \cdot 13$} & \multirow[b]{2}{*}{$\mathrm{m}$} \\
\hline & Start level - (higher point) & B & & \\
\hline & Stop level - (lower point) & C & 0.37 & $\mathrm{~m}$ \\
\hline & Depth dropped $(B-C)$ & $D$ & 0.76 & $\mathrm{~m}$ \\
\hline & Volume $(A \times D)$ & $E$ & $1 \cdot 37$ & $m^{3}$ \\
\hline & Time & $\mathrm{F}$ & 133 & $\mathrm{~s}$ \\
\hline & & & $2^{\prime} 13^{\prime \prime}$ & $\min , s$ \\
\hline & Flow (E/F) & G1 & $\begin{array}{r}0.01029 \\
10.29\end{array}$ & $\begin{array}{l}\mathrm{m}^{3} / \mathrm{s} \\
/ / \mathrm{s}\end{array}$ \\
\hline & tal vol. discharged $(\mathrm{G} 1 \times \mathrm{F})$ & $\mathrm{G} 2$ & $1368 \cdot 00$ & I \\
\hline
\end{tabular}

\begin{tabular}{|c|c|c|c|c|}
\hline \multirow{8}{*}{ 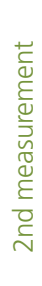 } & \multicolumn{2}{|l|}{ Pump stopped } & & \multirow[b]{2}{*}{$\mathrm{m}$} \\
\hline & Start level - (lower point) & C & $0 \cdot 37$ & \\
\hline & Stop level - (higher point) & B & $1 \cdot 15$ & $\mathrm{~m}$ \\
\hline & Depth raised $(B-C)$ & D & $0 \cdot 78$ & $\mathrm{~m}$ \\
\hline & Volume $(A \times D)$ & $E$ & $1 \cdot 40$ & $m^{3}$ \\
\hline & Time & $\mathrm{F}$ & 743 & $\mathrm{~s}$ \\
\hline & & & $12^{\prime} 23^{\prime \prime}$ & $\min$ \\
\hline & Flow (E/F) & G2 & $\begin{array}{r}0.00189 \\
1.89\end{array}$ & $\begin{array}{l}\mathrm{m}^{3} / \mathrm{s} \\
\mathrm{l} / \mathrm{s}\end{array}$ \\
\hline
\end{tabular}

stations (Table 4). Detailed calculations at one of the stations ( $\mathrm{St}$ George's Cross) are shown in Table 5 as an example.

St George's Cross Subway station was chosen for the pilot installation of a WSHP. Although not the highest flow, sump 1 (located near St George's Cross station) was chosen because this station has the shortest distance from the source point (water sump 1) to the sink point (station's ticket office).

A water sample from sump 1 was analysed by the Glasgow Scientific Services laboratory in Springburn, Glasgow, a division of Land and Environmental Services of the Glasgow City Council. The result of the chemical analysis for this water sample

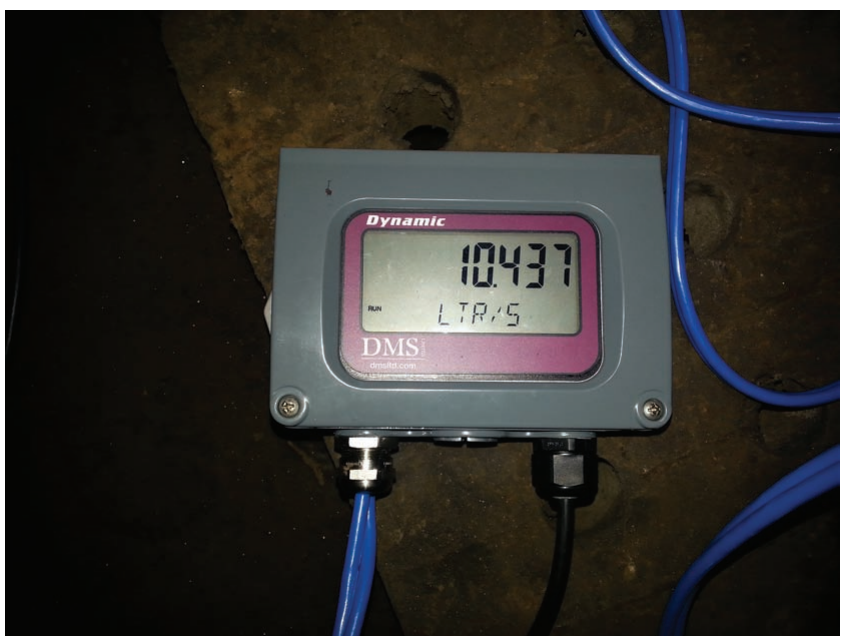

Figure 6. The ultrasonic flow meter showing the water flux (I/s) 
A heat energy recovery system from

tunnel waste water

Hytiris, Ninikas, Emmanuel, Aaen and Younger

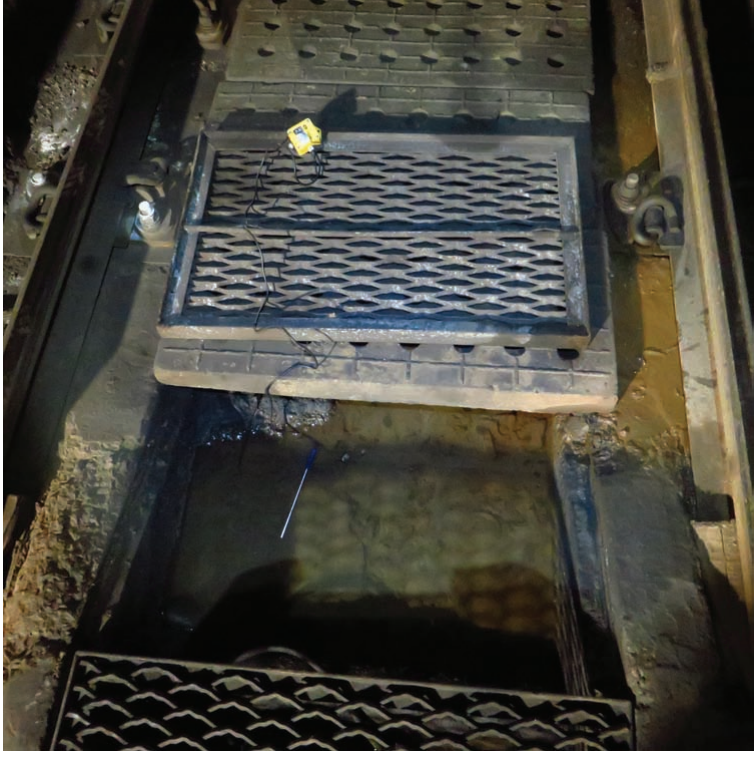

Figure 7. Digital thermocouple taking readings from a sump

indicated a low percentage of iron (Fe; $0.042 \mathrm{mg} / \mathrm{l}$ ), which allowed the heating system to be designed by using copper pipes.

The heat energy, $H$ (in kilowatts), can be calculated from the following formula (Banks, 2009)

1. $H=Q \times \rho \times S_{\mathrm{vc}} \times \Delta t$

where $Q$ is the water flow of the system $\left(\mathrm{m}^{3} / \mathrm{s}\right.$ ) (water flow in sump $\left.1=0.00307 \mathrm{~m}^{3} / \mathrm{s}\right), \rho$ is the density of the water $\left(\mathrm{kg} / \mathrm{m}^{3}\right)$ $\left(1000 \mathrm{~kg} / \mathrm{m}^{3}\right), S_{\mathrm{vc}}$ is the heat capacity of water $(\mathrm{kJ} /(\mathrm{kg} \mathrm{K}))$

\begin{tabular}{|c|c|c|c|c|c|}
\hline Month & Year & WF1: I/s & WT1: ${ }^{\circ} \mathrm{C}$ & OMT: ${ }^{\circ} \mathrm{C}$ & OMH: \% \\
\hline May & 2014 & $6 \cdot 7$ & $14 \cdot 17$ & $11 \cdot 40$ & 80 \\
\hline June & 2014 & $6 \cdot 3$ & $13 \cdot 45$ & $16 \cdot 70$ & 83 \\
\hline July & 2014 & $5 \cdot 3$ & 14.95 & $15 \cdot 80$ & 77 \\
\hline August & 2014 & $3 \cdot 9$ & $16 \cdot 03$ & $16 \cdot 00$ & 88 \\
\hline September & 2014 & 1.9 & $15 \cdot 40$ & $15 \cdot 00$ & 67 \\
\hline October & 2014 & $1 \cdot 8$ & $16 \cdot 13$ & $12 \cdot 00$ & 67 \\
\hline November & 2014 & $1 \cdot 8$ & $13 \cdot 72$ & $10 \cdot 00$ & 75 \\
\hline December & 2014 & $2 \cdot 0$ & $13 \cdot 20$ & $4 \cdot 10$ & 96 \\
\hline January & 2015 & $2 \cdot 1$ & $14 \cdot 13$ & $5 \cdot 80$ & 77 \\
\hline February & 2015 & $2 \cdot 2$ & $12 \cdot 12$ & $5 \cdot 70$ & 80 \\
\hline March & 2015 & $1 \cdot 5$ & $12 \cdot 81$ & $5 \cdot 40$ & 81 \\
\hline April & 2015 & 1.6 & 14.02 & $9 \cdot 40$ & 68 \\
\hline
\end{tabular}

WF1, water flow; WT1, water temperature; OMT, outdoor mean temperature; $\mathrm{OMH}$, outdoor mean humidity

Table 1. Readings from sump 1

\begin{tabular}{lccccc}
\hline Month & Year & WF2: I/s & WT2: ${ }^{\circ} \mathrm{C}$ & OMT: ${ }^{\circ} \mathrm{C}$ & OMH: \% \\
\hline May & 2014 & $6 \cdot 4$ & $14 \cdot 22$ & $11 \cdot 40$ & 80 \\
June & 2014 & $6 \cdot 8$ & $15 \cdot 28$ & $16 \cdot 70$ & 83 \\
July & 2014 & $4 \cdot 9$ & $13 \cdot 47$ & $15 \cdot 80$ & 77 \\
August & 2014 & $3 \cdot 6$ & $15 \cdot 76$ & $16 \cdot 00$ & 88 \\
September & 2014 & $2 \cdot 2$ & $15 \cdot 30$ & $15 \cdot 00$ & 67 \\
October & 2014 & $2 \cdot 1$ & $15 \cdot 88$ & $12 \cdot 00$ & 67 \\
November & 2014 & $1 \cdot 9$ & $15 \cdot 41$ & $10 \cdot 00$ & 75 \\
December & 2014 & $2 \cdot 1$ & $13 \cdot 45$ & $4 \cdot 10$ & 96 \\
January & 2015 & $2 \cdot 2$ & $14 \cdot 30$ & $5 \cdot 80$ & 77 \\
February & 2015 & $2 \cdot 1$ & $12 \cdot 62$ & $5 \cdot 70$ & 80 \\
March & 2015 & $1 \cdot 8$ & 13.93 & $5 \cdot 40$ & 81 \\
April & 2015 & $2 \cdot 0$ & 14.24 & 9.40 & 68 \\
\hline
\end{tabular}

WF2, water flow; WT2, water temperature; OMT, outdoor mean temperature; $\mathrm{OMH}$, outdoor mean humidity

Table 2. Readings from sump 2

$(4 \cdot 18 \mathrm{~kJ} /(\mathrm{kg} \mathrm{K}) ; 1 \mathrm{~kJ} / \mathrm{s}=1 \mathrm{~kW})$ and $\Delta t$ is the temperature difference $\left({ }^{\circ} \mathrm{C}\right)$ (temperature difference in sump $1=4^{\circ} \mathrm{C}$ ).

The average water flow from May 2014 to April 2015 for sump 1 (Table 1) is $3.07 \mathrm{l} / \mathrm{s}=0.00307 \mathrm{~m}^{3} / \mathrm{s}$, which will yield the following heat output: $H=0.00307 \times 1000 \times 4.18 \times 4=51.33 \mathrm{~kW}$.

However, the total heat load at St George's Cross station is $5 \cdot 2 \mathrm{~kW}$ (Table 4 ); thus, the provision of heating and DHW from sump 1 is feasible.

A basic design for the provision of heating and DHW from sump 1 was undertaken (Table 6), and a WSHP of $9 \mathrm{~kW}$ output was required to meet this subway station's heating and DHW demand.

Month Year WF17A: I/s WT17A: ${ }^{\circ} \mathrm{C}$ OMT: ${ }^{\circ} \mathrm{C} \quad \mathrm{OMH}: \%$

\begin{tabular}{lrrrrr}
\hline May & 2014 & $11 \cdot 5$ & $12 \cdot 60$ & $11 \cdot 40$ & 80 \\
June & 2014 & $12 \cdot 1$ & $13 \cdot 11$ & $16 \cdot 70$ & 83 \\
July & 2014 & $12 \cdot 1$ & $13 \cdot 62$ & $15 \cdot 00$ & 77 \\
August & 2014 & $10 \cdot 7$ & $13 \cdot 75$ & $16 \cdot 00$ & 88 \\
September & 2014 & $9 \cdot 8$ & $13 \cdot 80$ & $15 \cdot 00$ & 67 \\
October & 2014 & $9 \cdot 6$ & $12 \cdot 94$ & $12 \cdot 00$ & 67 \\
November & 2014 & $9 \cdot 4$ & $10 \cdot 71$ & $10 \cdot 00$ & 75 \\
December & 2014 & $9 \cdot 7$ & 10.65 & $4 \cdot 10$ & 96 \\
January & 2015 & $10 \cdot 3$ & $11 \cdot 84$ & $5 \cdot 80$ & 77 \\
February & 2015 & $10 \cdot 4$ & 11.62 & $5 \cdot 70$ & 80 \\
March & 2015 & $10 \cdot 6$ & $13 \cdot 63$ & $5 \cdot 40$ & 81 \\
April & 2015 & $10 \cdot 3$ & $13 \cdot 21$ & $9 \cdot 40$ & 68 \\
\hline
\end{tabular}

WF17A, water flow; WT17A, water temperature; OMT, outdoor mean temperature; $\mathrm{OMH}$, outdoor mean humidity

Table 3. Readings from sump 17A 
A heat energy recovery system from

tunnel waste water

Hytiris, Ninikas, Emmanuel, Aaen and Younger

\begin{tabular}{lcc}
\hline Station name & $\begin{array}{c}\text { Total design heat } \\
\text { load: W }\end{array}$ & $\begin{array}{c}\text { Total design heat } \\
\text { load: kW }\end{array}$ \\
\hline Kelvinbridge & 4755 & $4 \cdot 8$ \\
St George's Cross & 5185 & $5 \cdot 2$ \\
Cowcaddens & 3369 & $3 \cdot 4$ \\
Buchanan Street & 3778 & $3 \cdot 8$ \\
St Enoch & 4486 & $4 \cdot 5$ \\
Bridge Street & 4577 & $4 \cdot 6$ \\
West Street & 4029 & $4 \cdot 0$ \\
Shields Road & 4189 & $4 \cdot 2$ \\
Kinning Park & 2983 & $3 \cdot 0$ \\
Cessnock & 4106 & $4 \cdot 1$ \\
Ibrox & 3243 & $3 \cdot 2$ \\
Govan & 30331 & $30 \cdot 3$ \\
Partick & 45650 & $45 \cdot 7$ \\
Kelvinhall & 2599 & $2 \cdot 6$ \\
Hillhead & 6641 & $6 \cdot 6$
\end{tabular}

Table 4. Heat loads for the 15 subway stations (according to BS EN: 12831:2003)
The water from the sump will be pumped out through a submersible pump and rise up to the ticket office by way of an insulated 28-mm-dia. copper pipe (Figure 8). The heat pump and the associated equipment will be installed at the station cleaners' room at the ground floor (Figure 9).

The heat pump will feed four new low-temperature fan coil radiators, which will be sufficient for heating the station while replacing the existing four electric radiators at $2 \mathrm{~kW}$ each (Figure 10). This system is expected also to provide cooling as a by-product during summer months working in the reverse cycle.

\section{Discussion and conclusions}

One of the key findings of the study is the relatively stable and high water temperatures available within the Glasgow Subway tunnel system. For example Table 1 shows that the water temperature during the monitoring period was between 12 and $16^{\circ} \mathrm{C}$ and was never below $12^{\circ} \mathrm{C}$, even in the middle of winter. This compares favourably with typical shallow geothermal water temperatures of $9-10^{\circ} \mathrm{C}$ reported by Hytiris et al. (2016) in Glasgow. Therefore, a higher coefficient of performance $\left(\mathrm{COP}_{\mathrm{H}}\right)$ is likely. The $\mathrm{COP}_{\mathrm{H}}$ of a heat pump is the ratio of heating or cooling provided to the electrical energy consumed by the pump. A higher $\mathrm{COP}_{\mathrm{H}}$ equates to lower operating costs (Nave, 2016). Typically, a WSHP can perform at $\mathrm{COP}_{\mathrm{H}}$ of more than 3 , but the

\begin{tabular}{|c|c|c|c|c|c|}
\hline $\begin{array}{l}\text { St George's Cross } \\
\text { room name }\end{array}$ & $\begin{array}{c}\text { Transmission heat } \\
\text { load, } T_{\mathrm{i}}: \mathrm{W}\end{array}$ & $\begin{array}{c}\text { Ventilation heat } \\
\text { load, } V_{i}: \text { W }\end{array}$ & $\begin{array}{l}\text { Higher temperature } \\
\text { factor, } f: p . u \text {. }\end{array}$ & $\begin{array}{c}\text { Heating-up } \\
\text { capacity, } R_{\mathrm{H}, \mathrm{i}}: \mathrm{W}\end{array}$ & $\begin{array}{c}\text { Total design heat } \\
\text { load, } H_{\mathrm{L}, \mathrm{i}}: \mathrm{W}\end{array}$ \\
\hline Ticket office & $845 \cdot 62$ & $215 \cdot 37$ & 1 & $239 \cdot 20$ & $1300 \cdot 19$ \\
\hline Hallway (ground) & $448 \cdot 60$ & $74 \cdot 72$ & 1 & $82 \cdot 81$ & $606 \cdot 13$ \\
\hline Hallway (upper) & $337 \cdot 90$ & $36 \cdot 62$ & 1 & $40 \cdot 56$ & $415 \cdot 08$ \\
\hline Canteen & $987 \cdot 77$ & $232 \cdot 25$ & 1 & $257 \cdot 40$ & $1477 \cdot 43$ \\
\hline Female toilet & $276 \cdot 31$ & 78.83 & $1 \cdot 6$ & $58 \cdot 24$ & $448 \cdot 32$ \\
\hline Male toilet & $276 \cdot 31$ & 78.83 & 1.6 & $58 \cdot 24$ & $448 \cdot 32$ \\
\hline Store & $377 \cdot 76$ & $31 \cdot 36$ & 1 & $80 \cdot 21$ & $489 \cdot 33$ \\
\hline Total & $3550 \cdot 28$ & $747 \cdot 98$ & - & $816 \cdot 66$ & $5185 \cdot 00$ \\
\hline
\end{tabular}

Table 5. Thermal needs of St George's Cross Subway station offices

\begin{tabular}{|c|c|c|c|c|c|c|c|}
\hline Heating & $\begin{array}{l}\text { Input: } \\
\text { kW }\end{array}$ & $\begin{array}{l}\text { Output: } \\
\text { kW }\end{array}$ & Cost/kWh: $f$ & Cost/d (16 h): f & $\begin{array}{l}\text { Cost/year } \\
(210 \mathrm{~d}): \mathrm{f}\end{array}$ & $\begin{array}{c}\text { Carbon dioxide } \\
\text { emissions: } \mathrm{kg} \mathrm{CO}_{2} / \mathrm{kWh}\end{array}$ & By-product \\
\hline $\begin{array}{l}\text { Current: four electric } \\
\text { radiators }(2 \mathrm{~kW})\end{array}$ & 8 & 8 & $8 \times 0.12=0.96$ & $0.96 \times 16=15.36$ & $3225 \cdot 6$ & 0.47 & None \\
\hline Proposed: WSHP & 3 & 9 & $3 \times 0.12=0.36$ & $0.36 \times 16=5.76$ & $1209 \cdot 6$ & $0 \cdot 14$ & Cooling \\
\hline
\end{tabular}

St George's Cross Subway station total heat load $(5 \cdot 2 \mathrm{~kW})$

Table 6. St George's Cross station's current and proposed systems 

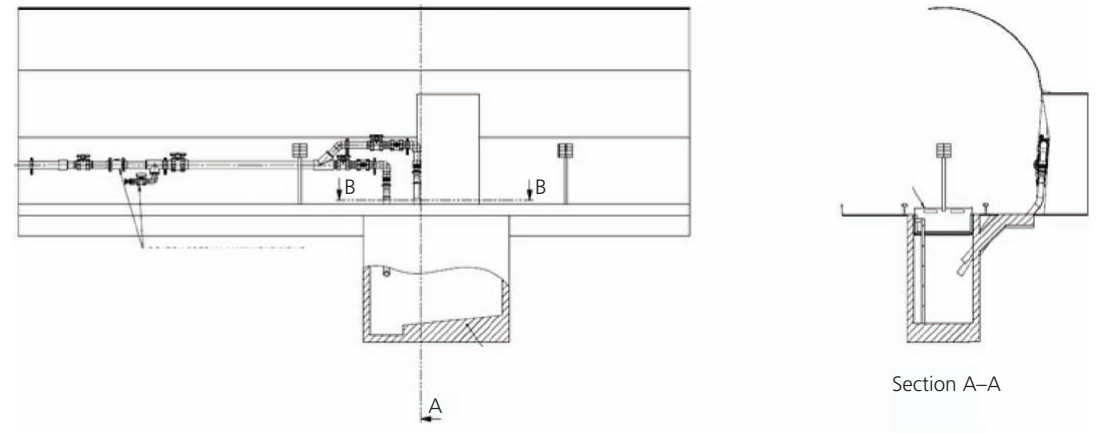

Section A-A

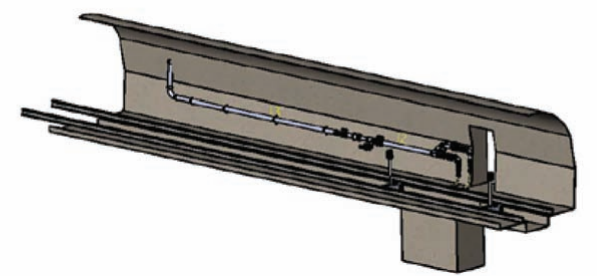

Figure 8. St George's Cross heating system diagram (track level)

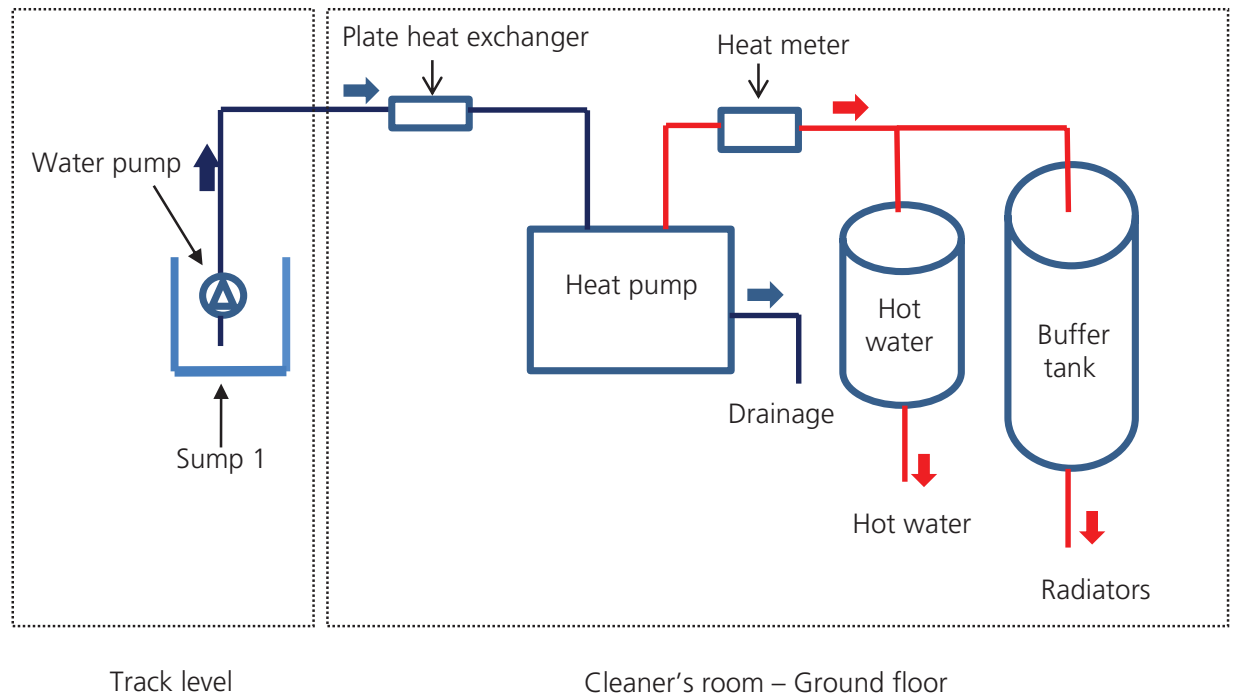

Figure 9. A simplified schematic diagram of the system at

St George's Cross station

higher intake temperature in this study's case would enable an even higher level of performance. This, however, needs to be verified by a field trial, and the installation of a WSHP at St George's Cross station is currently being completed for this purpose. Once the installation is complete, the authors intend to monitor the actual performance of the heat pump together with its electricity consumption to confirm the $\mathrm{COP}_{\mathrm{H}}$ of the system.

An indication of the likely cost and carbon dioxide savings ('carbon savings') of the proposed WSHP system is shown in Table 6. A WSHP system installed at just one station within the underground transport network could save over $£ 2000$ per annum and lead to over $70 \%$ reduction in carbon dioxide emissions. This compares favourably with typical GSHP installations (Table 7), which have a $67 \%$ reduction in carbon dioxide emission. Keeping in mind the calculations shown earlier are not for the most voluminous water flow (sump 17A has much higher flow rate - Table 3), greater cost and carbon savings are likely across the subway system. This may not only enable the utilisation of heat for the subway's own heating purposes but also provide a marketable and renewable commodity to nearby buildings.

An additional benefit of the proposed solution is the reduction in the amount of water that needs to be discharged to the local 


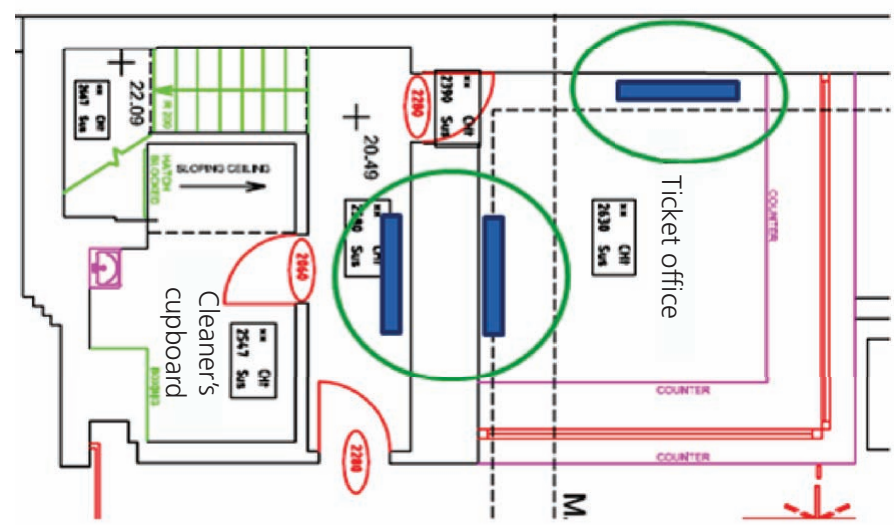

Ground floor

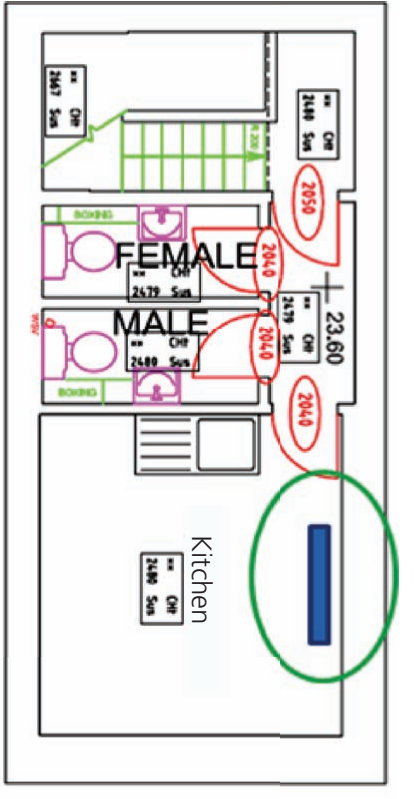

First floor

Figure 10. St George's Cross station drawing

\begin{tabular}{|c|c|c|c|}
\hline Fuel & Average price: $\mathrm{p} / \mathrm{kWh}$ & Carbon dioxide factor: $\mathrm{kg} \mathrm{CO} / \mathrm{kWh}$ & System efficiency: \% \\
\hline Gas & $4 \cdot 29$ & $0 \cdot 210$ & 90 \\
\hline Oil & $5 \cdot 36$ & $0 \cdot 246$ & 85 \\
\hline LPG & $8 \cdot 32$ & $0 \cdot 241$ & 85 \\
\hline Wood pellet & $4 \cdot 77$ & 0.044 & 90 \\
\hline Coal/solid fuel & $4 \cdot 00$ & $0 \cdot 380$ & 75 \\
\hline Electricity (standard rate) & $14 \cdot 05$ & $0 \cdot 540$ & 100 \\
\hline GSHP & $14 \cdot 05$ & $0 \cdot 177$ & 350 \\
\hline Air source heat pump & $14 \cdot 05$ & $0 \cdot 210$ & 350 \\
\hline
\end{tabular}

Table 7. Fuel prices and carbon dioxide factors

sewers. This is expected to reduce the operational hours of the existing pumps and potentially contribute to further energy savings.

The authors have thus shown that a problem that currently requires constant maintenance could be turned around into a source of renewable heat with considerable cost and carbon savings. Calculations of water flow rates from water ingress into the subway tunnels show that four of the 15 subway stations could benefit from harvesting heat from this source. Based on the performance of the pilot system currently being installed, a system of WSHPs could be scaled up across the subway network, providing significant benefits to the subway operator and contributing positively to Scotland's renewable heat energy targets.

\section{Acknowledgements}

This research was funded through a Knowledge Transfer Partnership scheme operated by Innovate UK. The partnership members are Glasgow Caledonian University and Strathclyde Partnership for Transport (SPT). The authors would also like to thank the following from the SPT: Mr Gordon McLennan, Mr Charles Hoskins and Mr Stuart McMillan, whose belief in the approach described herein made it possible for the authors to carry out the work.

\section{REFERENCES}

Banks D (2009) An Introduction to Thermogeology Ground Source Heating and Cooling, 2nd edn. Wiley-Blackwell Hoboken, NJ, USA, pp. 93, 99. 
Environmental Geotechnics

Volume 5 Issue EG5
A heat energy recovery system from

tunnel waste water

Hytiris, Ninikas, Emmanuel, Aaen and Younger
BKV Zrt (2011) Annual Report 2011. BKV Zrt, Budapest, Hungary. See http://static.bkv.hu/ftp/ftp/annual_report/ annualreport2011en.pdf (accessed 12/04/2016).

Branz (Building Research Association of New Zealand) (2015) Heat Pumps. Branz, Wellington, New Zealand. See: http://www. level.org.nz/energy/space-heating/heat-pumps/ (accessed 10/04/ 2016).

BSI (2003) BS EN 12831:2003: Heating systems in buildings. Method for calculation of the design heat load. BSI, London, UK.

Climate Change Act 2008 (2008) Elizabeth II. Chapter 27. Her Majesty's Stationery Office, London, UK. See http://www. legislation.gov.uk/ukpga/2008/27/contents (accessed 14/04/ 2016).

Ground Source Heat Pump Association (2015) What Is Ground Source Energy? Ground Source Heat Pump Association. See http://www.gshp.org.uk/gshp.htm (accessed 14/04/2016).

Hytiris N, Emmanuel R, Aaen B et al. (2016) Heat recovery from mineworkings: opportunities in the Glasgow area.
Environmental Geotechnics, http://dx.doi.org/10.1680/envgeo. 15.00007 .

NRC (Natural Resources Canada) (2015) What Is a Heat Pump and How Does It Work? NRC. Ottawa, ON, Canada. See http://www.nrcan.gc.ca/energy/publications/efficiency/heatingheat-pump/6827 (accessed 14/04/2016).

Nave CR (2016) HyperPhysics: Coefficient of Performance. Georgia State University, Atlanta, GA, USA. See http:// hyperphysics.phy-astr.gsu.edu/hbase/thermo/heatpump.html\#c3 (accessed 14/04/2016).

Scottish Government (2012) Scotland Beats 2011 Green Energy Target. Scottish Government, Edinburgh, UK. See http:/www.scotland.gov.uk/News/Releases/2012/03/ geenenergytargets29032012 (accessed 14/04/2016).

US DOE (US Department of Energy) (2015) Geothermal Heat Pumps. US DOE, Washington, DC, USA. See http://energy. gov/energysaver/geothermal-heat-pumps (accessed 09/04/2016).

\section{How can you contribute?}

To discuss this paper, please submit up to 500 words to the editor at journals@ice.org.uk. Your contribution will be forwarded to the author(s) for a reply and, if considered appropriate by the editorial board, it will be published as a discussion in a future issue of the journal. 